\title{
The influence of technology transfer on the formation of the innovative potential of the machine-building industry
}

\author{
Olga Vorontsova $^{1, *}$, Igor Savon $^{1}$, and Svetlana Gritzunova ${ }^{1}$ \\ ${ }^{1}$ Polytechnic Institute, DGTU, 347900 Taganrog, Russia
}

\begin{abstract}
The article attempts to substantiate the role of technology transfer in the process of formation of competitive advantages of Russia in international markets. The prospects of using the transfer of foreign technologies as a measure for the formation of the innovative economy of Russia and its regions are considered. One of such prospects is the solution of the problem of import substitution and development of own scientific and technical projects.
\end{abstract}

Mechanical engineering is the leading industry in the developed economies. The machinebuilding industry, providing the real sector with machinery and technical products and the largest consumer of production and technical products, is the mainstay in the system of interbranch relations in industry. The development of mechanical engineering ensures high employment of the population. At the same time, the technological level of modern machinebuilding production requires high qualification of workers, which contributes to the growth of the educational level of the population and the development of the country's scientific and technical potential. In the structure of manufacturing industries, the share of engineering products is $32 \%$ in France and the United States, $45 \%$ in Germany and $47 \%$ in Japan. In Russia, this indicator is $19.3 \%$. The number of employees in mechanical engineering makes up $38 \%$ of the total number of employed in the manufacturing industries [1].

The Russian machine-building complex is the basic branch of the economy and its technological core, fulfilling the function of ensuring the reproduction of the production and technological base for the branches of the real sector. The leading role of machine building is an indispensable condition for the existence of industrially developed countries and determines the pace and stability of their development. However, we note the weakening of the positions of Russian engineering industry over the past 30 years. In the 1980s. advanced technological potential was concentrated in the military-industrial complex, and in civil engineering new technologies were introduced slowly, and significant technological reserves remained unclaimed. With the exception of some advanced industries (power engineering, drilling equipment production), the production of Russian civil engineering was not in great demand by the markets of developed countries.

At the same time, the industrial and technological base of the economy of the USSR was formed almost entirely by investment equipment of domestic production. Since the 1990s.

\footnotetext{
*Corresponding author: gov555@inbox.ru
} 
and to the present time there is a further weakening of the potential of Russian civil engineering and a reduction in demand for Russian investment equipment for virtually all product groups.

Modernization of machine building is possible only on the basis of the integrated development of the science and innovation-intensive structure-forming core of the industry and industries that form the demand for metal-working equipment and means of automation and production control. It is obvious that for the development of ma-shinostroitelnyh production requires a stable demand for the chain "final demand - machine building - machine tool". There are no other realistic ways to develop the industry.

Insufficiency of innovative saturation of investments did not allow to significantly improve the structure of technologies. The increase in the efficiency of production in machine building is the highest among the processing industries. Despite the improvement of efficiency indicators in engineering, they lag far behind what modern technologies allow. Thus, for the period 2005-2015. The reduction in energy intensity was approximately $40 \%$, and labor productivity increased by $60 \%$ in the production of machinery and equipment and by $40 \%$ in the production of vehicles. The introduction of new production technologies makes it possible to increase production efficiency many times.

The calculations showed that to ensure innovation and technological development it is necessary that the innovative saturation of investments in high-tech industries is at least $50 \%$, and in medium-tech branches of high level - $45-48 \%$. In the modern world, the production of high-tech products with high added value is the most important condition for the formation of the country's competitiveness. Unfortunately, Russian products, which are quite competitive at the domestic, regional or Russian market, do not fully meet international standards.

With the reduction in production volumes, there was a significant decrease in the number of employed in the machine-building industries - so in 2015 the number of industrial and production personnel decreased by $70 \%$ compared with 1990 .

All over the world, such sectors as construction, engineering, aircraft construction, machine-tool construction and other sectors of the real economy are in the process of constantly generating and mastering modern technologies. From the point of view of technological safety and the impact of imports from countries that imposed sanctions against Russia, aviation industry, production of medical, optical equipment, engines and turbines, and pharmaceuticals remain the most problematic sectors of the economy. Comparatively favorable situation persists in the sector of computer technology and radio electronics, where China is the world leader in exports and a key partner of Russia.

Russia can be competitive in those industries where there is already a skilled workforce, experience in the commercialization of scientific developments and world recognition. For example, in information and communication technologies. Also, Russia can become a leading player in the emerging global markets - related to the increase in life expectancy, neuroscience, synthetic biology, etc. The basis for creating new products now lies in digitalization - the process of translating all kinds of information into digital. And here the chances of creating a competitive industry of Russia are very large.

However, the complexity of new technologies, as well as the speed of their development, no longer allow Russian scientific institutes and even large research centers working on orders from industrial corporations to count only on their own research developments and implementations. Therefore, one of the most important aspects of innovative processes is the transfer of technology. It is a transfer of the accumulated technological experience, scientific and technical knowledge, management technologies for the purpose of developing scientific and technical progress. The criterion for a successful transfer is the active use of the transferred technology for production purposes and the production of innovative products of high quality and demand. 
The international transfer of technologies implies the transfer of new technologies developed in one country, business entities (enterprises, organizations or firms) of another country. The international transfer of technologies promotes the integration of countries into a single economic space that unifies the economies of states in a globalized world.

The peak of international technology transfer studies occurred in the 1970s and 1980s, while research at the time focused mainly on studying the relationship between research and development with productivity in selected sectors of the economy or other indicators of the level of its technological development.

NestorTerleckyj (Terleckyj, 1974) identified two types of research and development impact on productivity in industrial sectors: direct impact on the industry in which research and development is conducted and indirect influence on other sectors through the use of intermediate and Investment products of industries in which research and development is carried out. N. Terletsky showed a relatively large strength of the indirect influence of research and development in comparison with direct. Moreover, a similar analysis, which he later made for non-industrial branches, showed a very small direct impact of research and development and a rather significant indirect one (Terleckyj, 1980).

Frederic Sherer (Scherer, 1982) developed a matrix of technological flows in the United States on the basis of data on research and development, implemented in 443 corporations from 276 industries, and national patent activity. Dividing research and development by branches of origin and use into domestic and imported from other industries, he proved a more pronounced influence of the latter on productivity growth. However, the results were contradictory. Two years later, a more detailed study by Zvi Griliches and Frank Lichtenberg [Grili-ches, Lichtenberg, 1984] showed a positive impact on the growth of research and development productivity in the industry of origin rather than in the field of use.

In the 1990s. a number of important studies were carried out in the USA. On the one hand, they showed that productivity growth in intermediate-output industries affects production growth in industries that consume it [Wolff, Nadiri, 1993]. On the other hand, based on the statistics on the share of imports in GDP and the accumulated investments in research and development, it was demonstrated that the aggregate factor productivity in the country essentially depends on investment in research and development of trading partners (Coe, Helpman, 1995). This result was an important step towards empirical confirmation of the transfer of technology through the import of goods.

The OECD Directorate for Science, Technology and Industry presented a detailed study of the transfer of technology through the importation of goods between the 10 member countries of the organization [Papaconstantinou et al., 1996], containing several inter- tion. First, research and development costs are mainly concentrated in only a few of the 35 industries: the first five of those in which they are conducted account for 60 to $80 \%$ of research and development costs, while the top five industries using research and development in the form of intermediate and investment goods, corresponds only to $40-50 \%$ of similar expenditures. Thus, the supply of high-tech goods is much more centralized than demand. In addition, if the latter is represented by different types of industries, then the supply of technologies is primarily based on the industries.

Secondly, in all the OECD countries in question, in addition to the United States, Germany and Japan - in Australia, Britain, Denmark, Italy, Canada, the Netherlands and France - technology import has proved to be more important than domestic research, which indicates its importance as a mechanism for the diffusion of technology. Finally, the authors divided the import of intermediate and investment goods and revealed almost equal importance of both channels with a slight advantage of the former.

As Wolfgang Keller (Keller, 2000) has shown with the example of eight OECD member countries, different from the typical (in terms of the share of technological leaders), the country structure of imports of commodities affects aggregate factor productivity, even in 
developed economies. According to V. Keller, due to differences in the structure of imports, this effect will have a greater impact on developing countries. His analysis also confirmed that productivity in OECD countries depends more on internal R \& D than on external ones. The forecast for developing countries is the opposite - the main channel for transfer of technologies is the import of high-tech goods.

For investment goods, similar studies have been conducted demonstrating that their imports play a big role in the transfer of technology in comparison with intermediate and final products [Xu, Wang, 1999]. Later, however, this result did not find an unambiguous confirmation - in different papers the value of investment and intermediate goods was estimated in different ways. The proposed later approach considered the differentiation of the structure of capital (imported investment goods) in the production function as one of the important sources of differences in the aggregate factor productivity of countries [Caselli, Wilson, 2004].

It was shown that high-tech types of capital (computer technology, aerospace, communication and electrical equipment) can be effectively used only in countries developed from the point of view of human capital, the volume of foreign direct investment (FDI) and the protection of intellectual property rights.

In subsequent works, a deeper study was made of the dependence of the efficiency of technological transfer through the import of goods from the characteristics of the country (Stone, Shepherd, 2011). It was demonstrated that access to finance and skilled labor is key for intermediary goods, and for investment, access to finance and macroeconomic stability.

Import as a channel of technological transfer was considered along with other factors, the pre-property among which in the scientific literature is given to foreign direct investment. In one of the first works on the import of goods and foreign direct investment as the transmission channels of technology [Lichtenberg, van Pottelsberghe de la Potterie, 1998], it was concluded that there is a weak effect on the productivity of incoming foreign direct investment, in contrast to Outgoing, with high importance of the port. This is confirmed by subsequent studies [Zhu, Jeon, 2007; Krammer, 2014].

Finally, there is evidence of a positive impact of imports of high-tech products for export. Thus, the import of intermediate goods from OECD countries caused a higher growth of enterprises' exports in China than imports from other countries. In general, imports of this category of goods brought a greater return in terms of export growth in industries with a high intensity of research and development [Feng et al., 2012]. The described influence is due to the growth of productivity generated by imports of intermediate and investment goods, reduction of costs, and access by local players to technolo- gies opening the way to foreign markets [Bas, Strauss-Kahn, 2014].

- It is advisable to limit the analysis of technology transfer by its main channel - import of high-tech goods;

- intermediate and investment high-tech goods can be considered together, since there is no indication that one of them is preferable as a technology transfer channel;

- The import of high-technology goods is an integral part of the foreign economic activity of modern economies, especially developing ones, therefore, when determining the dependence on imports, an effective cross-country comparison is effective;

- For an adequate assessment of the current technological level of the industry, the analysis should take into account the volumes of both imports and exports of goods.

It was the transfer of foreign technologies as the development strategy that was designated by the President of Russia V.V. Putin at the 19th St. Petersburg International Economic Forum, held in June 2015 [2]. The President of the Russian Federation stressed that the country is open to foreign partners, including investors in the Russian economy. The benefits of buyers and sellers of technology is obvious. For Russian enterprises, technology transfer 
will help increase competitiveness, boost exports. For sellers, this is one of the main tools for penetrating the vast Russian market and securing it on it.

Mechanisms for technology transfer are linked simultaneously with commodity expansion (the supply of equipment, turnkey projects of enterprises), and with accompanying transactions for the training of personnel, the supply of raw materials, components and materials, semi-finished products that bring additional income to the seller. Also, the intellectual property of the seller is capitalized: the conclusion of an agreement on the transfer of technology is often the result of the previous patenting of innovations abroad. The technology transfer allows foreign partners to integrate into the economic space of Russia, regardless of certain restrictions in the business partnership because of EU sanctions.

The transfer of foreign technologies is particularly important for the organization and development of entrepreneurial activities based on the application of high technology. For example, there is a direct relationship between the development of information and communication technologies and the economic characteristics of the regions of Russia. Information and communication technologies directly affect the production of the gross regional product of the subjects of the Russian Federation. It is proved that, the higher the level of development of information and communication technologies, the higher the level of regional social and economic development. The development of information and communication technologies in the modern world underlies the territorial distribution of the population, creating conditions for a high quality of life.

The transfer of technology became possible after Russia joined the World Trade Organization (WTO) in August 2012. Membership in the WTO saved the Russian Federation from the American Jackson-Vanik amendment, which in 1974 limited the range of imports, and first of all - of technology, to our country. A positive fact is the fact that Russian companies actively working on the international market received additional instruments of their own protection in defending their position in anti-dumping scandals.

The received foreign technologies can become an impulse for realization of projects of creation own innovative projects, development of the Russian sphere of research and development. In the long term, the transfer of technologies will contribute to the solution of the task of import substitution, the main economic guide of the state in the sanctions fight against the West.

The transfer of technology has contributed to innovative technological development and the solution of the problem of import substitution in many countries. For example, Germany's economic growth at the end of the twentieth century was based on the import of technology. As a result, the country topped the list of exporters of finished products, and now Germany implements the innovative strategy "Industry 4.0", which is based on new principles for the organization of high-tech industrial production.

China, which gained access to modern foreign technologies after accession to the WTO, has at times increased exports of finished goods. Currently, the country has relied on its own developments in the field of industrial robotics, engineering, biotechnological research, genetic engineering.

Brazil and Argentina to modernize the technological gap and meet consumer demand regularly modernize production through foreign technology transfers. And it is these technologies that formed the basis for national programs of robotization in agriculture.

In conclusion, we note the following. The innovative path of economic development adopted in the modern globalized world is impossible without access to high technologies. Their standards set the system of international competition, thus stimulating not so much commodity exchange as technical progress. Slow adaptation of new ideas and even slower introduction of new technologies do not leave Russia with chances for minimal advantages among foreign countries. Being outside the system, Russia condemns itself to self-isolation, technical backwardness, strengthening of raw materials orientation, preservation of forms of 
management that are unfit in market conditions. While national security increasingly depends on technological security. It, in turn, is determined by the state of the economy as a whole, and not just by the exporting industries. In order to close the gap with high-tech production, it is necessary to introduce technological innovations to Russian enterprises right now. And the transfer of foreign technologies can become one of the most effective mechanisms of this process.

\section{References}

1. Russian Statistical Yearbook. Stat. Sat. Moscow: Rosstat, 2005-2016

2. Speech of the President of the Russian Federation V.V. Putin at the XIX St. Petersburg International Economic Forum. rg.ru> 2015/06/19 / putin.html

3. Samarina V.P., Evaluation of the uneven socio-economic development of the subjects of the Central Black Earth Economic Region, Regional Economy: Theory and Practice. 2008, No. 8, P. 33-38.

4. Samarina V.P. "Pros and cons" of Russia's accession to the World Trade Organization for ferrous metallurgy, Economics in Industry, 2012, No 3, P. 23-26.

5. Skoufina T.P, The problem of the asymmetry of the economic development of space in modern research, Fundamental research, 2013, No 10-3, P. 650- 652.

6. Industry of Russia. 2000. Stat. Sat. Moscow: Goskomstat Rossii, 2000, 464 p.

7. Industrial production in Russia. 2016. Stat. Sat. Moscow: Rosstat, 2016, 347 p.

8. Labor and employment in Russia. Stat. Sat. Moscow: Rosstat, 2005-2015.

9. Suvorov A.V., Sukhorukova G.M., Methods for constructing a differentiated balance of cash incomes and expenditures of the population and forecast calculations based on it // Problems of forecasting, 2009, № 5. P. 35-50.

10. Korovkin A.G., Kuznetsov S.G., Dolgova I.N., Korolev I.B., Dynamics of highproductivity jobs in the Russian economy: the experience of macroeconomic evaluation, Forecasting economic growth: Materials of the International Scientific Conference timed to the 80th anniversary of the birth of Academician Yu.V. Yaremenko. M. MAX Press, 2017. P. 251-261.

11. Borisov V.N. and others. Forecasting innovative machine building: monograph, Otv. Ed. Panfilov VS M .: MAX Press, 2015. 180 p.

12. Investments in Russia. Stat. Sat. Moscow: Rosstat, 2005-2015.

13. Short-term economic indicators of the Russian Federation. http://www.gks.ru/wps/wcm/connect/rosstat_main/rosstat/en/statistics/publications/cata log/doc_1140080765391

14. Borisov V.N., Pochukaeva O.V., Innovative mechanical engineering as a factor of developing import substitution, in: Problems of forecasting, 2015, №, P. 31-42.

15. Customs statistics of foreign trade of the Russian Federation. Annual collection. Moscow: FCS of Russia, 2010-2016.

16. SPARK (System of professional analysis of markets and companies Inter-fax). Access mode: www.spark-interfax.ru 